\title{
Assessment of tactical principles in youth soccer players of different age groups
}

\author{
Israel Teoldo da Costa 1,2,3 \\ Júlio Garganta ${ }^{3}$ \\ Pablo Juan Greco ${ }^{2}$ \\ Isabel Mesquita ${ }^{3}$ \\ José Afonso ${ }^{3}$
}

https://doi.org/10.5628/rpcd.10.01.147

\author{
${ }^{1}$ University Center of Belo Horizonte \\ UNI-BH, Belo Horizonte, MG-Brazil \\ ${ }^{2}$ Federal University of Minas Gerais \\ UFMG, Belo Horizonte, MG-Brazil \\ ${ }^{3}$ Centre of Research, Education, Innovation and \\ Intervention in Sport, CIFI2D \\ Faculty of Sport, University of Porto, FADEUP, \\ Porto, Portugal
}

\begin{abstract}
The aim of this study was to analyze tactical behaviours performed by youth soccer players of different age groups according to ten core tactical principles of the game, in order to understand characteristics of each age group and their differences. The sample comprised a total of 300 youth soccer players (60 U11, 60 U13, 60 U15, 60 U17 and 60 U20), who have performed 17,239 tactical actions. Three tactical measures were analyzed (number of tactical actions, efficiency of tactical behaviours and tactical performance indices). Kruskal-Wallis $\mathrm{H}$ and Whitney U tests were applied to compare the values of tactical measures. Data reliability was assured by the Kappa of Cohen index. The results indicated forty statistical differences relative to the number of tactical actions performed, thirty-two statistical differences regarding the efficiency of tactical behaviours, and twenty statistical differences concerning tactical performance indices. In conclusion, one can conclude that as the age group increased, the players had a greater participation in the game, namely by performing of more tactical actions. In addition, the U15 and U17 groups presented no statistical differences in the efficiency of their tactical behaviours, while the U17 and U20 groups exhibited the biggest differences in the tactical performance indices.
\end{abstract}

Key-words: soccer, tactical performance, tactical behaviour, youth teams

\author{
RESUMO \\ Avaliação dos princípios tácticos em \\ jovens futebolistas de diferentes idades
}

O objetivo desse estudo consistiu na análise dos comportamentos táticos realizados por jovens jogadores de Futebol com base em dez princípios táticos fundamentais do jogo, de modo a verificar as características e as diferenças de cada grupo etário avaliado. A amostra foi constituída por 300 jovens jogadores (60 Sub-11, 60 Sub-13, 60 Sub-15, 60 Sub-17 e 60 Sub-20), que realizaram 17.239 ações táticas. Foram analisados três indicadores táticos (número de ações táticas, eficiência dos comportamentos táticos e indice de performance tática). Os testes de KruskalWallis $\mathrm{H} e$ Whitney $U$ foram utilizados para comparar os valores obtidos. A fiabilidade foi avaliada pelo índice de Kappa de Cohen. Dos resultados emergiram quarenta diferenças estatisticamente significativas para o número de ações táticas realizadas, trinta e duas para a eficiência dos comportamentos táticos e vinte para os índices de performance tática. Em suma, é possível afirmar que, à medida que o escalão etário aumentou, os jogadores demonstraram ter maior participação no jogo, nomeadamente realizando mais ações de jogo. Adicionalmente, os jogadores dos grupos Sub-15 e Sub-17 não apresentaram diferenças estatisticamente significativas em relação à eficiência dos seus comportamentos táticos, enquanto os grupos Sub-17 e Sub-20 exibiram as maiores diferenças com relação aos índices de performance tática.

Palavras-chave: futebol, performance tática, comportamento tático, escalões de formação 


\section{INTRODUCTION}

The identification and promotion of talent in soccer have received much attention of sport scientists, who have tried to describe some characteristics of expertise that can lead a young player to the highest level of performance ${ }^{(3,40)}$. Investigations that took into account the stages of sport participation have identified three different periods of formation, prior to the attainment of expert performance: the sampling years (6-12 years old), the specializing years (13-15 years old), and the investment years (more than 16 years old) $(5,8)$. To youth sport competition, the governing body of soccer, FIFA (Fédération Internationale de Football Association), accredits international tournaments for players with ages between 15 and 21 years old. According to these stages, many soccer Clubs have youth development programs that aim to provide conditions leading to the complete development of the abilities of athletes from early ages. In addition, many soccer Clubs provide a specific training environment for players with distinguished skills from under 11 (U11) until under 20 years old (U20) groups, where they can practice activities in specific and systematic training programs to develop their soccer abilities towards fulfilling their potential(28). Probably, all these clubs provide excellent conditions for talented players from as early as 11 years old, believing that a 10year commitment to a high level of training is the minimum requirement to reach the expert level 10 , 18). Specifically in the context of soccer, Helsen et al.(17) found that around nine years into their career expert players increased both training duration and intensity and they suggested that this was a necessary requirement for reaching expert level performance, i.e., the international level of competition. Moreover, as stated by Silva, Fernandes and Celani(32), each of the sports developmental stages has particularities and demands related with game knowledge and learning. Baker and Côté(3) claim that this ability to perceive essential information from the playing environment, to correctly interpret this information, and then to select the appropriate response is a key characteristic for expert performance in team ball sports. In the context of soccer, researchers have highlighted that the high number of actions performed by the players without the ball raises the solicitations of the tactical abilities and cognitive skills underlying decision-making(12, 15, 26, 33). Hence, they suggest that teachers and coaches should use a training model underpinned in tactical features and basic guidelines in order to facilitate decision-making and collective organization. This way, the phases of training should follow and represent the demands of game situations on the organization and efficiency of the players' movements, according to the team goals, in order to maximize their learning and performance ${ }^{(21,43)}$. Accordingly, it seems to make sense that the establishment of the training phases, preparation of training sessions and assessment of the development of player's skills should be based on tactical principles, since they provide athletes the possibility to attain effective tactical solutions for game situations ${ }^{(14,20,35)}$.

Despite expert superiority in different components of tactical knowledge and decision-making having been consistently demonstrated in several studies $(1,2,4)$, little concern has been devoted to how such abilities can be developed $(3,25,33)$. Furthermore, sport scientists have advocated that more attention needs to be focused on developmental issues of athletes who have been engaged in sport development stages, such as relative age effects, motivation, tactical awareness and physiological aspects $(9,19,23,29,30)$. Therefore, the purpose of this paper was to analyze tactical behaviours performed by youth soccer players of different age groups according to ten core tactical principles of the game, in order to understand characteristics of each age group and their differences.

\section{METHODS \\ Sample}

Three hundred youth soccer players participated in the study [U11 ( $n=60), \mathrm{U13}(\mathrm{n}=60), \mathrm{U15}(\mathrm{n}=60)$, $\mathrm{U} 17(\mathrm{n}=60)$ and $\mathrm{U} 20(\mathrm{n}=60)]$. Furthermore, this study comprised the observation of 17,239 tactical actions $(2,637$ were performed by U-11 players, 3,306 by U-13 players, 3,480 by U- 15 players, 3,988 by U-17 players and 3,828 by U-19 players). Data from throw-ins, free kicks and situations in which the player did not move were not analyzed.

\section{Procedures}

Applied Method

The System of Tactical Assessment in Soccer (FUT-SAT), developed in the Centre for Team Sports Studies of 
Table 1: Categories, sub-categories and variables assessed by FUT-SAT

\begin{tabular}{|c|c|c|c|}
\hline Categories & Sub-Categories & Variables & Definitions \\
\hline \multirow[t]{10}{*}{ Tactical Principles } & \multirow[t]{5}{*}{ Offensive } & Penetration & Movement of player with the ball towards the goal line. \\
\hline & & Offensive Coverage & Offensive supports to the player with the ball. \\
\hline & & Depth Mobility & Movement of players between the last defender and goal line. \\
\hline & & Width and Length & Movement of players to extend and use the effective play-space. \\
\hline & & Offensive Unity & $\begin{array}{l}\text { Movement of the last line of defenders towards the offensive midfield, } \\
\text { in order to support offensive actions of the teammates. }\end{array}$ \\
\hline & \multirow[t]{5}{*}{ Defensive } & Delay & Actions to slow down the opponent's attempt to move forward with the ball. \\
\hline & & Defensive Coverage & $\begin{array}{l}\text { Positioning of off-ball defenders behind the "delay" player, } \\
\text { providing defensive support. }\end{array}$ \\
\hline & & Balance & $\begin{array}{l}\text { Positioning of off-ball defenders in reaction to movements of attackers, } \\
\text { trying to achieve the numerical stability or superiority in the opposition } \\
\text { relationship. }\end{array}$ \\
\hline & & Concentration & $\begin{array}{l}\text { Positioning of off-ball defenders to occupy vital spaces and protect } \\
\text { the scoring area. }\end{array}$ \\
\hline & & Defensive Unity & $\begin{array}{l}\text { Positioning of off-ball defenders to reduce the effective play-space } \\
\text { of the opponents. }\end{array}$ \\
\hline \multirow[t]{4}{*}{ Place of Action } & \multirow[t]{2}{*}{ Offensive Midfield } & Offensive Actions & Offensive actions performed in the offensive midfield. \\
\hline & & Defensive Actions & Defensive actions performed in the offensive midfield. \\
\hline & \multirow[t]{2}{*}{ Defensive Midfield } & Offensive Actions & Offensive actions performed in the defensive midfield. \\
\hline & & Defensive Actions & Defensive actions performed in the defensive midfield. \\
\hline \multirow[t]{10}{*}{ Action Outcomes } & \multirow[t]{5}{*}{ Offensive } & Shoot at goal & $\begin{array}{l}\text { When a player shoots at goal, and (a) scores a goal, (b) the goalkeeper } \\
\text { makes a save, (c) the ball touches one of the goalposts or the crossbar. }\end{array}$ \\
\hline & & $\begin{array}{l}\text { Keep possession } \\
\text { of the ball }\end{array}$ & $\begin{array}{l}\text { When team players execute passes to each other and } \\
\text { keep up with the ball. }\end{array}$ \\
\hline & & $\begin{array}{l}\text { Earn a foul, win a } \\
\text { corner or throw-in }\end{array}$ & $\begin{array}{l}\text { When the match is stopped due to a foul, corner or throw-in; the team } \\
\text { that was attacking KEEPS possession of the ball. }\end{array}$ \\
\hline & & $\begin{array}{l}\text { Commit a foul, five } \\
\text { away a corner or throw in }\end{array}$ & $\begin{array}{l}\text { When the match is stopped due to a foul, corner or throw-in; the } \\
\text { possession of the ball CHANGES to the team that was in defence. }\end{array}$ \\
\hline & & Loss of ball possession & When the attacking team loses the ball possession. \\
\hline & \multirow[t]{5}{*}{ Defensive } & $\begin{array}{l}\text { Regain the ball } \\
\text { possession }\end{array}$ & When the defensive players regain the ball possession. \\
\hline & & $\begin{array}{l}\text { Earn a foul, win a } \\
\text { corner or throw-in }\end{array}$ & $\begin{array}{l}\text { When the match is stopped due to a foul, corner or throw-in and the } \\
\text { possession of the ball CHANGES to the team that was in defence. }\end{array}$ \\
\hline & & $\begin{array}{l}\text { Commit a foul, five } \\
\text { away a corner or throw in }\end{array}$ & $\begin{array}{l}\text { When the match is stopped due to a foul, corner or throw-in; } \\
\text { the team that was attacking KEEPS possession of the ball. }\end{array}$ \\
\hline & & $\begin{array}{l}\text { Ball possession of } \\
\text { the opponent }\end{array}$ & When the defensive players do not regain the ball possession. \\
\hline & & $\begin{array}{l}\text { Take a shot at } \\
\text { own goal }\end{array}$ & $\begin{array}{l}\text { When the defensive team takes a shot at their own goal, and (a) takes a } \\
\text { goal, (b) the goalkeeper makes a save, }(\mathrm{c} \text { ) the ball touches one of the } \\
\text { goalposts or the crossbar. }\end{array}$ \\
\hline
\end{tabular}


the Faculty of Sport, University of Porto, was used to collect data ${ }^{(6)}$. This system encompasses two macrocategories, seven categories and 76 variables, and was designed to assess the tactical actions performed by the players (with and without the ball), according to ten core tactical principles of the soccer game ${ }^{(7}$, 44). Additionally, the evaluation takes into account the location where the action takes place and the outcome (for details see Table 1).

Based on this information, three tactical measures were analyzed: the number of tactical actions performed by the players, the efficiency of tactical behaviours and the tactical performance indices. The assessment of efficiency of tactical behaviours was based on the degree to which the skill's execution matches the established criteria for correct mechanical execution ${ }^{(31)}$. To calculate the tactical performance indices, the efficiency of tactical behaviours was taken into account, as well as the field position where the actions took place and the obtained result, in agreement with the goal of the action, i.e., the effectiveness of the actions(31).

The field test is designed in a space of 36 meters long by 27 meters wide, and requires the player to play for four minutes (3 vs. 3 with goalkeepers). With the exception of the offside rule, all laws of the game are applied in the field test.

\section{Data collection}

Data for this study was gathered in four different clubs with directors' permission. The players who were voluntarily involved in the study have regular participation in regional soccer tournaments. Prior to the test, a brief explanation of its purposes was given to the players. The teams were formed randomly and the players were wearing numbered vests in order to facilitate their identification. A thirty-second period had been granted to familiarize players with the test, after which the game began.

\section{Materials}

The games were recorded with a digital camera (PANASONIC NV - DS35EG). Digital videos were then transferred to a laptop ( $L G$ model E500 CPU Intel T2370) via cable (IEEE 1394) and converted into ".avi" files. Software Utilius VS ${ }^{\circledR}$ and Soccer Analyzer ${ }^{\circledR}$ were used for data processing. The first software was utilized to record and save the tactical actions, while the second was built specifically for the FUT-SAT; it inserts special references in the video, allowing unerring evaluation of the position and movement of the players in the field.

\section{Data Analysis}

Data analysis comprises three steps. The first consists in analyzing the tactical actions performed by the players during the match. The unit of analysis considers the ball possession, encompassing one of three situations: (a) the player touches the ball at least three consecutive times; (b) the player performs a positive pass (allowing the team to keep possession); (c) the player performs a kick to the goal(11). The second step involves the assessment, classification and registration of tactical actions analyzed during the first step. It is supported by a framework of tactical behaviour analysis of FUT-SAT and two software packages: Soccer Analyser ${ }^{\circledR}$ and Utilius VS ${ }^{\circledR}$. The third step involves the calculation of the variables' scores, with reference to the test, through a system developed for Excel for Windows ${ }^{\circledR}$ (Figure 1). Through the insertion of data from the second step, this system allows the automatic calculation of all variables present in FUT-SAT.

\section{Statistical Analysis}

Descriptive statistics (frequencies, means and standard deviations) were carried out to characterize the sample. The number of tactical actions performed by the players, the efficiency of tactical behaviours and the tactical performance indices obtained by five groups (U11 to U20) were compared using the Kruskal-Wallis H test. For the comparison of each pair of groups, Mann-Whitney U test was applied. The level of significance was set at $\mathrm{p} \leq 0.05$. To determine the reliability of the observation, the test-retest method was used to obtain the stabilityreliability coefficient. Five observers were trained to review 2275 tactical actions, representing $13.2 \%$ of the sample. This percentage is above the value of reference $(10 \%)$ recommended by the literature ${ }^{34)}$. The results reveal inter-observers' agreement coefficients between $0.81(\mathrm{SD}=0.03)$ and $0.91(\mathrm{SD}=$ 0.02 ) and intra-observers' agreement coefficients between $0.85(\mathrm{SD}=0.02)$ and $0.92(\mathrm{SD}=0.01)$. 


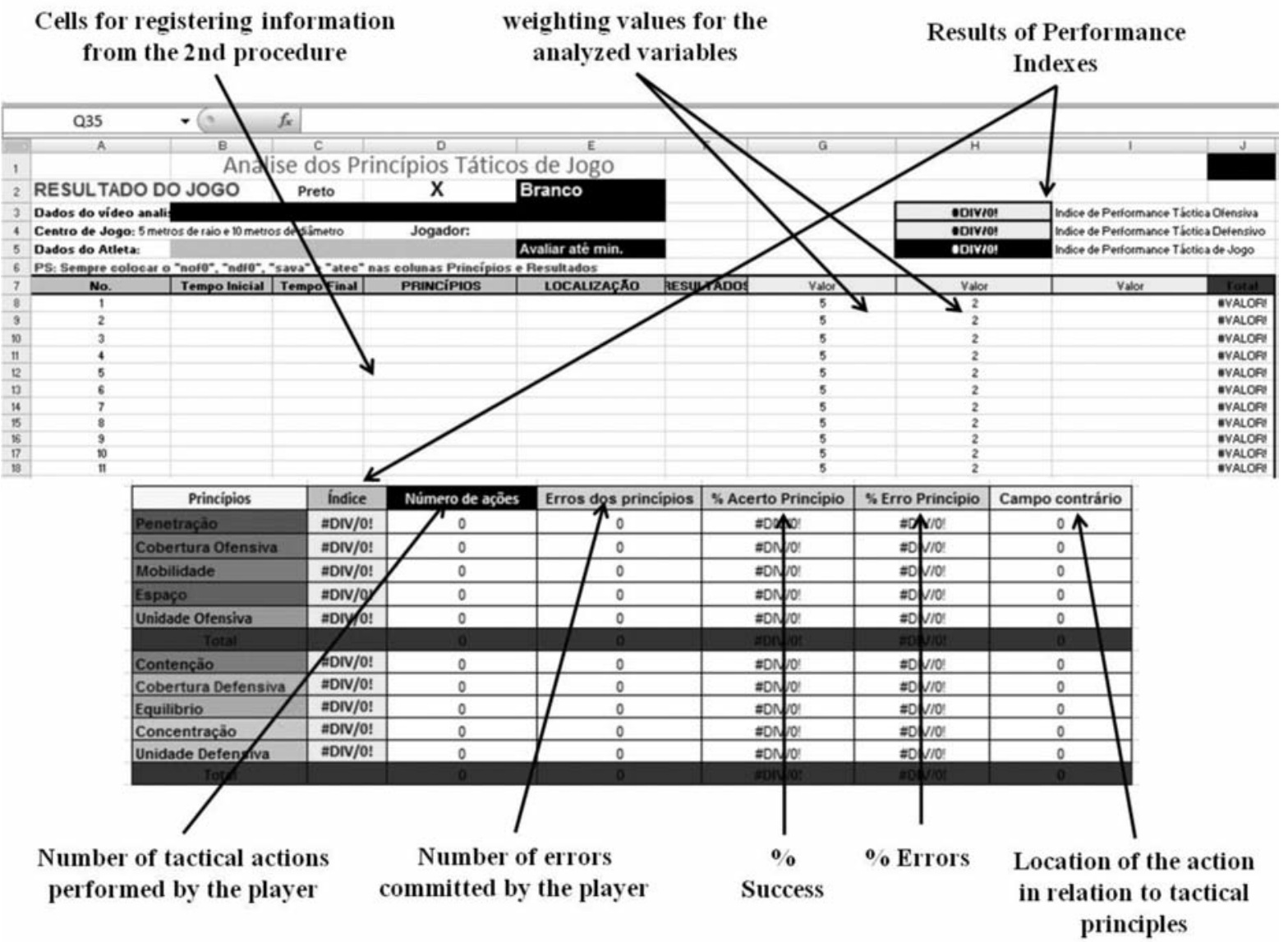

Figure 1. System for calculation of test variables; developed for Excel for Windows ${ }^{\circledR}$.

These values are above the conventional level of acceptance (0.61) (22).

All statistical procedures were done using software EQS 6.1 and SPSS 17.0.

\section{RESULTS}

Table 2 presents the means and standard deviations concerning tactical actions performed by players from all groups. The comparison among the groups indicated forty statistical differences. Only the "depth mobility" and "delay" principles exhibited no significant differences. The "concentration" principle presented the greatest number of differences among youth soccer teams. The offensive and defensive principles more frequently performed by players from all groups were "width and length" and "defen- sive unity", respectively. On the other hand, "defensive coverage" was the defensive principle least used by players. In the same order, "depth mobility" and "penetration" were the offensive principles less executed by U11 until U17 and U20 players.

Regarding the groups in study, it was verified that only U13 and U15 did not show statistical differences. All the other groups presented statistical differences concerning the quantity of tactical actions performed by the players. The highest number of differences was observed between U11 and U20 groups, and the lowest number between U17 and U20 players. Globally, statistical differences between the groups increased as the age difference broadened, i.e., U11 showed more differences when compared with U20 and less when contrasted with U13. 
Table 2. Tactical actions performed by players for each tactical principle of the game.

\begin{tabular}{|c|c|c|c|c|c|c|}
\hline \multirow[t]{2}{*}{ Principles } & \multicolumn{5}{|c|}{ Tactical Actions } & \multirow[b]{2}{*}{ Sig. $(p \leq 0,05)^{*}$} \\
\hline & U11 & U13 & U15 & U17 & U20 & \\
\hline \multicolumn{7}{|l|}{ Offensive } \\
\hline Penetration & $2.58 \pm 1.74$ & $3.30 \pm 1.69$ & $3.35 \pm 1.90$ & $3.50 \pm 1.95$ & $3.68 \pm 1.77$ & $1,4,8$ \\
\hline Offensive Coverage & $5.52 \pm 3.13$ & $7.27 \pm 3.69$ & $7.27 \pm 3.99$ & $8.63 \pm 5.62$ & $8.48 \pm 3.74$ & $1,2,3,4$ \\
\hline Width and Length & $6.13 \pm 4.17$ & $9.62 \pm 5.30$ & $10.27 \pm 4.100$ & $11.58 \pm 5.100$ & $10.93 \pm 5.95$ & $1,2,3,4,5$ \\
\hline Depth Mobility & $2.60 \pm 4.00$ & $2.75 \pm 2.61$ & $3.22 \pm 3.63$ & $3.47 \pm 2.69$ & $3.78 \pm 1.92$ & \\
\hline Offensive Unity & $2.83 \pm 2.62$ & $3.13 \pm 2.87$ & $3.42 \pm 2.88$ & $4.60 \pm 3.02$ & $4.57 \pm 2.68$ & $3,4,5,6,7,8$ \\
\hline \multicolumn{7}{|l|}{ Defensive } \\
\hline Delay & $4.53 \pm 2.69$ & $5.52 \pm 2.73$ & $5.50 \pm 2.86$ & $6.02 \pm 3.13$ & $5.87 \pm 3.02$ & \\
\hline Defensive Coverage & $1.00 \pm 1.12$ & $1.12 \pm 1.21$ & $1.90 \pm 2.38$ & $3.22 \pm 4.06$ & $3.42 \pm 2.88$ & $3,4,5,6,8$ \\
\hline Balance & $3.25 \pm 1.81$ & $4.40 \pm 2.24$ & $4.38 \pm 2.15$ & $5.12 \pm 2.90$ & $4.95 \pm 2.94$ & $1,2,3,4$ \\
\hline Concentration & $3.08 \pm 2.21$ & $4.47 \pm 2.96$ & $4.38 \pm 2.62$ & $5.87 \pm 4.03$ & $7.87 \pm 3.46$ & $1,2,3,4,5,6,7,8,9$ \\
\hline Defensive Unity & $11.23 \pm 3.805$ & $13.43 \pm 4.908$ & $13.42 \pm 4.10$ & $19.92 \pm 4.96$ & $14.03 \pm 4.607$ & $1,2,3,4$ \\
\hline
\end{tabular}

*Significant statistics differences ( $p \leq 0.05$ ) between: 1 U11 and U13: Penetration ( $Z=-2.44 ; p=0.015$ ). 0ffensive Coverage ( $Z=-2.63 ; p=0.009$ ). Width and Length $(Z=-3.66 ; p<0.001)$. Balance ( $Z=-2.85 ; p=0.004)$. Concentration ( $Z=-2.67 ; p=0.007)$ and Defensive Unity ( $Z=-2.57 ; p=0.010)$. 2 U11 and U15: 0ffensive Coverage $(Z=-2.46 ; p=0.014)$. Width and Length $(Z=-4.84 ; p<0.001)$. Balance $(Z=-3.03 ; p=0.002]$. Concentration $(Z=-2.83 ; p=0.005]$ and $D e f e n s i v e ~ U n i t y ~(Z=-4.10$; $p<0.001$ ). 3 U11 and U17: Offensive Coverage ( $Z=-2.98 ; p=0.003$ ). Width and Length $(Z=-5.55 ; p<0.001$ ). Offensive Unity ( $Z=-3.58 ; p<0.001)$. Defensive Coverage $(Z=-2.68 ; p=0.007)$. Balance $(Z=-3.70 ; p<0.001)$. Concentration $(Z=-6.74 ; p<0.001)$ and Defensive Unity $(Z=-2.16 ; p=0.031) .4$ U11 and U20: Penetration ( $Z=-3.71$; $p=0.002)$. Offensive Coverage $(Z=-4.41 ; p<0.001)$. Width and Length $(Z=-4.76 ; p<0.001)$. Offensive Unity $(Z=-3.69 ; p<0.001)$. Defensive Coverage $(Z=-5.62$; $p<0.001)$. Balance $(Z=-2.30 ; p=0.021)$. Concentration $(Z=-4.70 ; p<0.001)$ and Defensive Unity $(Z=-3.21 ; p=0.001) .5 U 13$ and $U 17:$ Width and Length $(Z=-2.10$; $p=0.036)$. Offensive Unity ( $Z=-3.04 ; p=0.002)$. Defensive Coverage $(Z=-2.26 ; p=0.024$ ) and Concentration $(Z=-4.86 ; p<0.001)$. 6 U13 and U20:0ffensive Unity ( $Z=-$ 3.07; $p=0.002$ ]. Defensive Coverage ( $Z=-5.36 ; p<0.001$ ) and Concentration ( $Z=-2.35 ; p=0.019)$. 7 U15 and U17: Offensive Unity ( $Z=-2.49 ; p=0.013$ ) and Concentration $(Z=-5.01 ; p<0.001)$. 8 U15 and U20: Penetration $(Z=-2.23 ; p=0.026)$. Offensive Unity $(Z=-2.70 ; p=0.007)$. Defensive Coverage $(Z=-3.69 ; p<0.001]$ and Concentration $(Z=-2.40 ; p=0.016$ ). $9 \cup 17$ and $U 20$ : Concentration $(Z=-2.87 ; p=0.004$ ).

Table 3 displays means and standard deviations for the efficiency of tactical behaviours, according to each tactical game principle. The comparison of groups showed thirty-two statistical differences. Only three principles, "offensive coverage", "depth mobility" and "balance", revealed no significant differences. The defensive principles "concentration" and "defensive unity" presented the greatest number of differences among youth soccer teams. The lower values regarding the efficiency of tactical behaviours were linked with the "delay" principle in the defensive phase, and "offensive unity" and "penetration" principles in the offensive phase. The best ratings were obtained in the "depth mobility" and "concentration" principles. It was also observed that all groups showed significant statistical differences on the rating of efficien- cy of tactical behaviours, except when comparing U15 with U17. The highest numbers of significant differences were placed in U17 group, with five differences to U11 and U13 groups, and four differences to U20, although it did not show any differences to U15.

Table 4 displays the tactical performance indices obtained by players in each tactical principle. The data showed that the players were heterogeneous concerning their performance. Comparing the performance indices among the groups, twenty statistical differences were found. These differences concern five out of ten core principles, namely two offensive and three defensive principles. In spite of being only two offensive principles ("offensive coverage" and "depth mobility"), they concentrated 
Table 3. Efficiency of tactical behaviours by groups for each tactical principle of the game.

\begin{tabular}{|c|c|c|c|c|c|c|}
\hline \multirow[t]{2}{*}{ Principles } & \multicolumn{5}{|c|}{ Efficiency of tactical behaviours } & \multirow[b]{2}{*}{ Sig. $(p \leq 0,05)^{*}$} \\
\hline & U11 & U13 & U15 & U17 & U20 & \\
\hline \multicolumn{7}{|l|}{ Offensive } \\
\hline Penetration & $61.75 \pm 42.60$ & $68.07 \pm 21.28$ & $76.90 \pm 32.65$ & $82.22 \pm 29.72$ & $86.94 \pm 22.71$ & $1,3,4$ \\
\hline Offensive Coverage & $91.91 \pm 23.12$ & $92.95 \pm 16.59$ & $90.65 \pm 22.52$ & $91.05 \pm 19.61$ & $94.23 \pm 08.97$ & \\
\hline Width and Length & $76.10 \pm 42.41$ & $78.33 \pm 41.55$ & $81.60 \pm 33.05$ & $86.71 \pm 35.95$ & $88.13 \pm 29.24$ & $3,4,6,7$ \\
\hline Depth Mobility & $94.60 \pm 17.12$ & $94.62 \pm 18.70$ & $94.96 \pm 10.74$ & $96.30 \pm 13.57$ & $96.75 \pm 15.07$ & \\
\hline Offensive Unity & $66.82 \pm 41.65$ & $68.80 \pm 41.72$ & $72.42 \pm 38.51$ & $75.26 \pm 33.85$ & $89.44 \pm 35.66$ & $3,5,6,8,9$ \\
\hline \multicolumn{7}{|l|}{ Defensive } \\
\hline Delay & $29.80 \pm 26.81$ & $30.22 \pm 25.52$ & $39.06 \pm 26.64$ & $40.05 \pm 25.17$ & $43.62 \pm 23.59$ & $4,5,6,7,8$ \\
\hline Defensive Coverage & $36.94 \pm 44.37$ & $37.10 \pm 38.27$ & $42.86 \pm 46.36$ & $48.59 \pm 45.71$ & $66.64 \pm 36.09$ & $4,7,9$ \\
\hline Balance & $37.25 \pm 33.54$ & $39.69 \pm 31.65$ & $40.09 \pm 30.11$ & $43.63 \pm 29.94$ & $48.05 \pm 28.37$ & \\
\hline Concentration & $60.61 \pm 34.76$ & $64.58 \pm 30.20$ & $75.76 \pm 33.36$ & $7.7 .7 \pm 28.46$ & $81.12 \pm 27.50$ & $2,3,5,6,8,9$ \\
\hline Defensive Unity & $36.71 \pm 24.81$ & $46.75 \pm 26.59$ & $62.36 \pm 27.39$ & $66.97 \pm 20.79$ & $67.50 \pm 26.47$ & $2,3,5,6,8,9$ \\
\hline
\end{tabular}

\footnotetext{
*Significant statistics differences ( $p \leq 0.05$ ) between: 1 U11 and U13: Penetration ( $Z=-3.28 ; p=0.001$ ). 2 U11 and U15: Concentration (Z=-2.37; $p=0.018$ ) and Defensive Unity $(Z=-3.94 ; p<0.001)$. 3 U11 and U17: Penetration ( $Z=-2.62 ; p=0.009)$. Width and Length $(Z=-2.81 ; p=0.005)$. Offensive Unity $(Z=-2.74 ; p=0.006)$. Concentration ( $Z=-3.62 ; p<0.001$ ) and Defensive Unity ( $Z=-6.08 ; p<0.001)$. 4 U11 and U20: Penetration ( $Z=-3.20 ; p=0.001)$. Width and Length ( $Z=-2.87 ; p=0.004)$. Delay $(Z=-2.35 ; p=0.019)$ and Defensive Coverage $(Z=-3.36 ; p=0.001)$. 5 U13 and U15: Offensive Unity ( $Z=-2.13 ; p=0.033)$. Delay ( $Z=-2.13 ; p=0.034)$. Concentration ( $Z=-3.24 ; p=0.001$ ) and Defensive Unity $(Z=-2.96, p=0.003$ ). 6 U13 and U17: Width and Length ( $Z=-2.61 ; p=0.009)$. Offensive Unity ( $Z=-3.00$; $p=0.003)$. Delay $(Z=-1.98 ; p=0.048)$. Concentration $(Z=-4.69 ; p<0.001)$ and Defensive Unity $(Z=-5.19 ; p<0.001)$. 7 U13 and U20: Width and Length ( $Z=-2.64$; $p=0.008$ ). Delay ( $Z=-3.06 ; p=0.002$ ) and Defensive Coverage $(Z=-2.38 ; p=0.017) .8$ U15 and U20: Offensive Unity ( $Z=-1.98 ; p=0.048)$. Delay ( $Z=-1.98 ; p=0.048)$. Concentration ( $Z=-2.29 ; p=0.022$ ) and Defensive Unity ( $Z=-4.03 ; p<0.001$ ). 9 U17 and U20: Offensive Unity ( $Z=-2.98 ; p=0.003$ ). Defensive Coverage ( $Z=-4.08$; $p<0.001)$. Concentration $(Z=-3.81 ; p<0.001)$ and Defensive Unity $(Z=-5.84 ; p<0.001)$.
}

twelve statistical differences, while the other three defensive principles ("defensive coverage", "balance" and "defensive unity") presented eight differences. Moreover, the "depth mobility" principle had the lowest tactical performance indices (U11 to U20), and the "offensive coverage" (U11) and "width and length" (U13 to U20) principles had the highest values in the offensive phase. In the defensive phase, the "defensive unity" (U11 to U15) and "defensive coverage" (U17 and U20) principles presented the highest tactical performance indices, and "defensive coverage" (U11 to U15) and "delay" had the lowest ones. Significant differences were found between all age groups. The highest number of performance differences was observed between U17 and U20 groups.

\section{DISCUSSION}

The results indicated that as the age group increased, the players had a greater participation on the game, i.e. they perform more tactical actions. In addition, data showed that U15 and U17 players presented no statistical differences in the efficiency of tactical behaviours, although these two groups exhibited many differences to the other groups. In terms of tactical performance indices, the biggest differences were found between 17 and 20 years of age, probably because it is in this period that the transfer of players to first teams occurs(3). In the literature, this stage of development has been considered as a critical period in the process of development for the player's future career(37). At a competitive level, the transition to the first team is associat- 
Table 4. Performance Indices obtained by players for each tactical principle of the game.

\begin{tabular}{|c|c|c|c|c|c|c|}
\hline \multirow[t]{2}{*}{ Principles } & \multicolumn{5}{|c|}{ Tactical Performance Indices } & \multirow[b]{2}{*}{ Sig. $(p \leq 0,05)^{*}$} \\
\hline & U11 & U13 & U15 & U17 & U20 & \\
\hline \multicolumn{7}{|l|}{ Offensive } \\
\hline Penetration & $47.70 \pm 33.64$ & $49.34 \pm 21.32$ & $50.62 \pm 25.37$ & $49.19 \pm 22.56$ & $56.00 \pm 19.91$ & \\
\hline Offensive Coverage & $52.22 \pm 21.40$ & $53.68 \pm 14.66$ & $55.25 \pm 15.33$ & $56.99 \pm 12.99$ & $59.57 \pm 09.70$ & $3,5,6,7,8,10$ \\
\hline Width and Length & $42.74 \pm 28.96$ & $55.76 \pm 35.01$ & $58.17 \pm 26.83$ & $64.06 \pm 28.64$ & $67.51 \pm 25.84$ & \\
\hline Depth Mobility & $41.53 \pm 12.68$ & $44.31 \pm 12.24$ & $45.92 \pm 09.75$ & $46.06 \pm 10.73$ & $48.07 \pm 09.38$ & $1,2,3,4,9,10$ \\
\hline Offensive Unity & $43.75 \pm 34.53$ & $45.85 \pm 29.59$ & $50.66 \pm 32.24$ & $52.18 \pm 22.59$ & $52.07 \pm 23.41$ & \\
\hline \multicolumn{7}{|l|}{ Defensive } \\
\hline Delay & $22.80 \pm 17.13$ & $25.30 \pm 09.93$ & $26.48 \pm 10.56$ & $25.12 \pm 09.45$ & $26.18 \pm 10.26$ & \\
\hline Defensive Coverage & $20.65 \pm 25.54$ & $20.67 \pm 19.39$ & $26.20 \pm 24.92$ & $29.52 \pm 19.04$ & $31.43 \pm 19.02$ & $4,7,10$ \\
\hline Balance & $22.51 \pm 19.24$ & $24.44 \pm 11.97$ & $23.92 \pm 09.25$ & $27.22 \pm 13.96$ & $31.24 \pm 15.83$ & $7,9,10$ \\
\hline Concentration & $20.90 \pm 16.42$ & $25.64 \pm 12.82$ & $26.56 \pm 11.58$ & $26.57 \pm 07.50$ & $28.30 \pm 09.21$ & \\
\hline Defensive Unity & $23.06 \pm 07.16$ & $25.97 \pm 07.12$ & $26.95 \pm 08.57$ & $26.52 \pm 06.48$ & $29.99 \pm 07.04$ & 9,10 \\
\hline
\end{tabular}

*Significant statistics differences ( $p \leq 0.05$ ) between: 1 U11 and U13: Depth Mobility ( $Z=-2.59 ; p=0.010$ ). 2 U11 and U15: Depth Mobility ( $Z=-2.17 ; p=0.030$ ). 3 U11 and U17: Offensive Coverage ( $Z=-2.46 ; p=0.014$ ] and Depth Mobility ( $Z=-3.11 ; p=0.002$ ]. 4 U11 and U20: Depth Mobility ( $Z=-5.00 ; p<0.001$ ] and Defensive Coverage ( $Z=-3.37 ; p=0.001$ ). 5 U13 and U15: Offensive Coverage ( $Z=-2.39 ; p=0.017$ ]. 6 U13 and U17: Offensive Coverage ( $Z=-5.00 ; p<0.001$ ]. 7 U13 and U20:0ffensive Coverage ( $Z=-2.65 ; p=0.008$ ]. Defensive Coverage $(Z=-2.85 ; p=0.004)$ and Balance $(Z=-2.84 ; p=0.005) .8$ U15 and U17:0ffensive Coverage ( $Z=-3.12 ; p=0.002$ ). 9 U15 and U20: Depth Mobility ( $Z=-2.69 ; p=0.007$ ). Balance ( $Z=-3.26 ; p=0.001$ ) and Defensive Unity ( $Z=-2.66 ; p=0.008)$. 10 U17 and U20:0ffensive Coverage ( $Z=-$ 2.88; $p=0.004$ ]. Depth Mobility ( $Z=-3.30 ; p=0.001$ ]. Defensive Coverage $(Z=-3.84 ; p<0.001)$. Balance $(Z=-3.12 ; p=0.002]$ and Defensive Unity ( $Z=-3.03 ; p=0.002$ ].

ed with the expectation of a higher level of performance, alongside a reduced tolerance for failure. Consequently, players must seek to achieve the best performance to give further sequence to their sports career, integrating the professional team or being negotiated with other clubs $(30)$.

Sport researchers have also highlighted that the distinction between performance and behaviours' efficiency is important for scientists and practitioners, since many of the typical interventions employed by coaches have differential effects on these two issues $(4$, 24, 27). Although players may have learnt a particular tactical behaviour, they may not always perform according to their potential because of the effect of various extraneous or performance variables such as the opponent or technical and physical characteristics(38). In this study, this has occurred with the younger groups (U11 to U15), where the performance indices of the players did not show many statis- tical differences. Furthermore, it was possible to verify that the effectiveness of the actions was the most significant factor affecting the tactical performance indices of U17 and U20 players. This inference is possible because, in addition to the efficiency of tactical behaviours, the calculation of tactical performance indices takes into account the effectiveness of the tactical actions. Thus, data displayed in Table 3 indicated only four statistical differences and similar absolute values in the efficiency of tactical behaviours of these two groups, but Table 4 showed more differences, suggesting that effectiveness of the actions was decisive to the better performance of U-20 group, i.e. besides having executed tactical actions with success, they also got better action outcomes. Whilst the performance indices have fluctuated substantially (lowest value $=20.65$; highest value $=$ $67.51)$ between the age groups evaluated in this study, sport specialists have assumed that learning 
can be deemed to have taken place if the improvement in performance is relatively permanent during sports developmental stages $(8,38)$. In this study, it was verified that there were improvements in the tactical performance indices values with increasing age. Thus, it was confirmed that there were less inter-individual variances and better performances in the older groups, probably reflecting the learning progress of the players, and also the most restricted selection concerning several constraints imposed by training and competitive demands.

The results of this study provide important information concerning the tactical behaviours performed by players of different development stages in soccer. They may be associated with other research findings that have reported the importance of tactical constraints for the player and team's development in team $\operatorname{sports}(4,13,16,20,36,39,41,42)$. It has also been reported in literature that teaching tactics focused on general rather than the specific issues has been at least one potential reason for the lack of strong investigation findings that prove the relationship between tactical teaching and performance(24). According to these authors (p.190), "The emphasis has been placed on generalizing skills, knowledge, or decisionmaking of games from one setting to another or from one sport to another, rather than from practice conditions to games.". In this sense, it is expected that the present study, together with other research findings, can provide a step forward in these matters, since the evaluation of players has been made concerning core tactical principles. The assessment based on these principles allows obtaining knowledge about difficulties and potentials of athletes in specific tactical behaviours. In addition, it permits the setting of specific training sessions for players according to the characteristics described in this paper, in order to provide them opportunities to try new or different combinations of behaviours that will eventually enable them to reach their goals of further sport development ${ }^{(43)}$. To sum up, this study showed that the involvement of players in the game has increased with age, possibly a consequence of having participated in more training stages. Moreover, the athletes performed more tactical actions related to the "width and length" and "defensive unity" principles of offensive and defensive phases, respectively.
Regarding the efficiency of tactical behaviours, it was observed that the players of U15 and U17 groups presented no statistical difference between them, but they were the groups that had more statistical differences to other groups. Furthermore, it was verified that the tactical performance indices from U17 and U20 groups presented more statistical differences and that these distinctions happened due the effectiveness of the actions obtained by U20 players. Future research should extend the current findings by examining other groups or competitive levels, in an attempt to verify whether the tactical behaviours are similar or different when performed by other players. Beyond that, it may be interesting to investigate if efficiency of tactical behaviours and tactical performance indices vary according to the players' positions or if there are relative age effects within each group.

\section{ACKNOWLEDGMENT}

Supported by the Programme AlBan, the European Union Programme of High Level Scholarships for Latin America, scholarship n E07D400279BR".

\section{CORRESPONDENCE}

\section{Israel Teoldo da Costa}

Centro de Estudos em Cognição e Ação (CECA)

Escola de Educação Física, Fisioterapia e Terapia Ocupacional da UFMG

Av. Presidente Antônio Carlos, 6627- Pampulha

Belo Horizonte - MG

Cep: $31.310-250$

Fone/Fax: OXX (31) 3499-2325

E-mail: israelteoldo@gmail.com 


\section{REFERENCES}

1. Abernethy B, Baker J, Côté J (2005). Transfer of pattern recall skills may contribute to the development of sport expertise. Applied Cognitive Psychology, 19: 705-18.

2. Abernethy B (1991). Visual search strategies and decisionmaking in sport. International Journal of Sport Psychology, 22: 189-210.

3. Baker J, Côté J, Abernethy B (2003). Sport-Specific practice and the development of expert decision-making in team ball sports. Journal of Applied Sport Psychology, 15: 1225.

4. Blomqvist M, Vänttinen T, Luhtanen P (2005). Assessment of secondary school students' decision-making and gameplay ability in soccer. Physical Education \& Sport Pedagogy, 10(2): 107-19

5. Bloom BS (1985). Developing talent in young people. New York: Ballantine.

6. Costa I, Garganta J, Greco P, Mesquita I (2009). Avaliação do Desempenho Tático no Futebol: Concepção e Desenvolvimento da Grelha de Observação do Teste "GR33GR". Revista Mineira de Educação Física, 17(2): 36-64.

7. Costa IT, Garganta J, Greco PJ, Mesquita I (2009). Princípios Táticos do Jogo de Futebol: conceitos e aplicação. Revista Motriz, 15(3): 657-68

8. Côté J, Baker J, Abernethy B (2003). From play to practice: A developmental framework for the acquisition of expertise in team sports. In: Starkes J, Ericsson KA, editors. Expert Performance in Sports: Advances in Research on Sport Expertise. Champaign, IL: Human Kinetics Publishers, 89113

9. Côté J, Ericsson KA, Beamer M (2005). Tracing the development of athletes using retrospective interview methods: a proposed interview and validation procedure for reported information. Journal of Applied Sport Psychology, 17: 1-19

10. Ericsson AK, Krampe RR, Romer TC (1993). The Role of Deliberate Practice in the Acquisition of Expert Performance. Psychological Review. 100(3): 363-406

11. Garganta J (1997). Modelação táctica do jogo de futebol - estudo da organização da fase ofensiva em equipas de alto rendimento. Tese de Doutoramento, Universidade do Porto, Portugal (not published)

12. Garganta J (2006). Idéias e competências para "pilotar" o jogo de futebol. In: Tani G, Bento JO, Petersen RDS, editors. Pedagogia do Desporto. Rio de Janeiro: Guanabara Koogan, 313-26

13. Gréhaigne J-F, Godbout P, Bouthier D (1999). The Foundations of Tactics and Strategy in Team Sports. Journal of Teaching in Physical Education, 18: 159-74

14. Gréhaigne JF, Godbout P (1998). Formative Assessment in Team Sports in a Tactical Approach Context. JOPERD, 69(1): 46-51

15. Gréhaigne JF, Godbout P, Bouthier D (1997). Performance assessment in team sports. Journal of Teaching in Physical Education, 16(4): 500-16

16. Gréhaigne JF, Wallian N, Godbout P (2005). Tactical-decision learning model and students' practices. Physical Education \& Sport Pedagogy, 10(3): 255-69

17. Helsen W, Starkes J, Hodges N (1998). Team sports and the theory of deliberate practice. Journal of Sport \& Exercise Psychology, 20: 12-34.

18. Helsen W, Van Winckel J, Williams AM (2005). The relative age effect in youth soccer across Europe. Journal of
Sports Sciences, 23(6): 629-36

19. Helsen WF, Hodges NJ, Van Winckel J, Starkes JL (2000). The roles of talent, physical precocity and practice in the development of soccer expertise. Journal of Sports Sciences, 18: $727-36$

20. Holt NL, Strean WB, Bengoechea EG (2002). Expanding the teaching games for understanding model: new avenues for future research and practice. Journal of Teaching in Physical Education, 21: 162-76

21. Janelle CM, Hillman CH (2003). Expert Performance in Sport: Current Perspectives and Critical issues. In: Starkes J, Ericsson KA, editors. Expert Performance in Sports: Advances in Research on Sport Expertise. Champaign, IL: Human Kinetics Publishers, 19-47.

22. Landis JR, Koch GC (1977). The measurement of observer agreement for categorical data. Biometrics. 33: 1089-91

23. Laurin R, Nicolas M, Lacassagne M (2008). Effects of a personal goal management program on school and football self-determination motivation and satisfaction of newcomers within a football training centre. European Sport Management Quarterly, 8: 83-99

24. Lee M-A, Ward P (2009). Generalization of tactics in tag rugby from practice to games in middle school physical education. Physical Education \& Sport Pedagogy, 14(2): 189207

25. Luhtanen P, Valovirta E, Blomqvist M, Brown E (1998). Game understanding and game performance in soccer and modified soccer in finnish youth players. In: Hughes M, Tavares F, editors. IV World Congress of Notational Analysis of Sport. Porto, Portugal: Multitema, 78-87.

26. McPherson S (1994). The Development of Sport Expertise: Mapping the Tactical Domain. Quest, 46(2): 223-40

27. Oslin JL, Mitchell SA, Griffin LL (1998). The Game Performance Assessment Instrument (GPAI): development and preliminary validation. Journal of Teaching in Physical Education, 17(2): 231-43

28. Reilly AT, Williams AM, Nevill A, Franks A (2000). A multidisciplinary approach to talent identification in soccer. Journal of Sports Sciences, 18: 695-702

29. Reilly T, Bangsbo J, Franks A (2000). Anthropometric and physiological predispositions for elite soccer. Journal of Sports Sciences, 18:669-83

30. Relvas H, Richardson D, Gilbourne D, Littlewood M (2010). Youth development in elite European football: structure, philosophy, and working practices. In: Drust B, Reilly T, Williams M, editors. International Research in Science and Soccer: Proceedings of the First World Conference on Science and Soccer. London: Routledge, 29-35.

31. Rink J (1993). Teacher education - A focus on action. Quest, 45: 308-20

32. Silva FM, Fernandes L, Celani FO (2001). Desporto de crianças e jovens - um estudo sobre as idades de iniciação. Revista Portuguesa de Ciências do Desporto, 1(2): 45-55

33. Vaeyens R, Lenoir M, Williams AM, Matthys S, Philippaerts RM (2010). The mechanisms underpinning decision-making in youth soccer players: an analysis of verbal reports. In: Drust B, Reilly T, Williams M, editors. International Research in Science and Soccer: Proceedings of the First World Conference on Science and Soccer. London: Routledge, 21-28

34. Tabachnick B, Fidell L (2007). Using Multivariate Statistics. 5 ed. New York: Harper \& Row Publishers 
35. Tenga A, Kanstad D, Ronglan LT, Bahr R (2009).

Developing a New Method for Team Match Performance Analysis in Professional Soccer and Testing its Reliability. International Journal of Performance Analysis of Sport.9: 8-25

36. Turner A, Martinek T (1995). Teaching for understanding: a model for improving decision making during game play. Quest, 47: 44-63

37. Vaeyens R, Coutts AJ, Philippaerts RM (2005). Evaluation of the "under-21 rule": Do young adult soccer players benefit? Journal of Sports Sciences, 23: 1003-12

38. Williams AM, Horn RR, Hodges N (2003). Skill Acquisition. In: Reilly T, Williams AM, editors. Science and Soccer. London: Routledge, 198-213.

39. Williams AM, Jamie SN (2009). Some constraints on recognition performance in soccer. In: Araújo D, Ripoll H, Raab M, editors. Perspectives on cognition and action in sport. New York: Nova Science Publishers, Inc., 95-108.

40. Williams AM, Ward P (2003). Perceptual expertise: development in sport. In: Starkes J, Ericsson K, editors. Expert Performance in Sports: Advances in Research on Sport Expertise. Champaign, IL: Human Kinetics Publishers, 219-50.

41. Williams AM, Davids K (1995). Declarative knowledge in sport: a by-product of experience or a characteristic of expertise? Journal of Sport \& Exercise Psychology, 17(3): 25975

42. Williams AM, Davids K, Bruwitz L, Williams J (1993). Cognitive knowledge and soccer performance. Perceptual $\mathcal{E}$ Motor Skills, 76(2): 579-93

43. Wilson GE (2002). A framework for teaching tactical game knowledge. Journal of Physical Education, Recreation and Dance, 73(1): 20-6.

44. Worthington E (1974). Learning \& teaching soccer skills. Califórnia: Hal Leighton Printing Company 